\title{
Reproductive Biology and Herkogamy of Psychotria elata (Rubiaceae), a Distylous Species of the Tropical Rain Forests of Costa Rica
}

\author{
Celice Alexandre Silva ${ }^{1 *}$, Jorge Arturo Lobo Segura ${ }^{2}$ \\ ${ }^{1}$ Department of Biological Science, Centro de Pesquisas, Estudos e Desenvolvimento Agro-Ambientais (CPEDA), \\ State University of Mato Grosso, Tangará da Serra, Brazil \\ ${ }^{2}$ School of Biology, University of Costa Rica, San Pedro, Costa Rica \\ Email: ${ }^{*}$ celice@unemat.br
}

Received 21 November 2014; accepted 11 February 2015; published 25 February 2015

Copyright (C) 2015 by authors and Scientific Research Publishing Inc.

This work is licensed under the Creative Commons Attribution International License (CC BY).

http://creativecommons.org/licenses/by/4.0/

(c) (i) Open Access

\section{Abstract}

The floral morphology, breeding system and pollinators of four natural populations of Psychotria elata (Rubiaceae), found in tropical rainforests of Costa Rica, were examined. Anisoplethy and distylous morphology were observed in all studied populations. The number of flowers per inflorescence was significantly higher in the most abundant morph $(p<0.005)$ and the number of open flowers/inflorescence/day was similar between the morphs $(p>0.05)$. Reciprocal herkogamy was detected in only one of the morphs in one population. Breakdown of the heteromorphic incompatibility system was observed in the populations Tirimbina and Rara Avis. Pollen production was significantly lower in thrum morphs of Tirimbina. Seedless fruits were formed in two of the four populations. One-seeded fruits were formed in all populations and were predominant in thrum morphs of Tirimbina $(9.15 \%)$ and Zurqui $(75 \%)$. According to our visitation records, hummingbirds, butterflies and moths are the main pollinators of $P$. elata flowers.

\section{Keywords}

Disassortative Mating, Floral Morphology, Geographic Variation, Morph Ratio, Pollinators

\section{Introduction}

Heterostyly species generally have a heteromorphic incompatibility system, where, in most cases, fruits are

${ }^{*}$ Corresponding author.

How to cite this paper: Silva, C.A. and Segura, J.A.L. (2015) Reproductive Biology and Herkogamy of Psychotria elata (Rubiaceae), a Distylous Species of the Tropical Rain Forests of Costa Rica. American Journal of Plant Sciences, 6, 433-444. http://dx.doi.org/10.4236/ajps.2015.63049 
formed by legitimate pollinator-mediated crosses between short-styled flowers with anthers positioned above the stigma (thrum-morph) and flowers with long-style and stigma positioned above the anthers (pin-morph) [1].

In heterostyly, the disassortative mating between morphs depends on differences between morphs in the place of pollen deposition and reception that enhance pollen transfer between morphs, and occasionally to an intramorph incompatibility system [2]. Under these conditions, the equilibrium frequency is a 1:1 ratio of thrum and pin morphs (isoplethy) [3]. However, deviations from this frequency (anisoplethy) may be caused by stochastic processes, changes in the heteromorphic incompatibility, by differences between the morph fitness [4] [5]; or as a result of changes in the pollinator guilds and floral traits [6] [7].

Changes in flower morphology may affect the position of the reproductive organs (anthers and stigma) and pollen dispersal [8] [9] and can determine the reproductive success rates of each morph [10], resulting in a shift from isoplethy to anisoplethy or even to monomorphism. In addition, the breakdown of the self-incompatibility system may be the result of a loss of pollinators [11], and could evolve in parallel with floral morphometry affecting herkogamous reciprocity.

These secondary changes may be the result of some floral traits, declines in female and male fitness or when selfing is expressed in the population [12]. In some species, the variation in floral and reproductive traits within and among populations, is a field with ample opportunities of investigation on the effect of floral variation in the mating system [13] [14].

Studies of evolutionary heterostyly models suggest that when there is no reciprocal herkogamy of stamens and pistils between alternative (pin and thrum) morphs and in case of a breakdown of the heteromorphic incompatibility system, this mismatch determines low reciprocity between morphs and low disassortative mating [2].

The objective of this study was to evaluate the reproductive biology and herkogamy between floral pin and thrum morphs in populations of Psychotria elata (Rubiaceae) in different locations of the Atlantic Slop of the Costa Rica. To this end, we 1) assessed the sex ratio of thrum and pin morphs in populations; 2) quantified the pattern of variation in two key aspects of floral morphology (corolla length and herkogamy) within and among populations; 3) checked a possible breakdown of the self-incompatibility system between floral morphs; 4) recorded the occurrence of pollinators; and 5) we evaluated the reproductive success of each morph in the populations studied.

\section{Material and Methods}

\subsection{Study Areas and Species}

The study was carried out at forest sites along the Atlantic Slope in Costa Rica, located within the Central Volcanic Cordillera Conservation Area (CVCCA) in Costa Rica, from January to June 2013. The vegetation in the CVCCA consists predominantly of moist and very moist tropical rainforest, with about $4000-6000 \mathrm{~mm}$ of annual rainfall [15].

Psychotria elata (Sw.) Hammel is a distylous shrub with a height of 0.5 to $5 \mathrm{~m}$; glabrous leaves; solitary terminal, inflorescences capitate to semi-hemispheric globose, surrounded by orange red basal bracts. The flowers are surrounded by about $16 \mathrm{~mm}$ high glabrous, sessile, white bracteoles. The flowers are visited by butterflies and hummingbirds, have sessile ovary; and blue ovoid fruits that become black at maturity. P. elata is distributed along forest edges and interiors of 30 to $1700 \mathrm{~m}$ elevation from Central America to Colombia. It flowers and fruits year-round with flowering peak from January to August [16].

\subsection{Sample Size and Frequency of Floral Morphs in Populations}

During January and February 2013, in a visit to the CVCCA in Costa Rica, we selected four natural P. elata populations located at four sites (Tirimbina (TIR) $\left(10^{\circ} 41^{\prime} 584^{\prime \prime} \mathrm{N}\right.$ and $84^{\circ} 12^{\prime} 218^{\prime \prime} \mathrm{W}, 171 \mathrm{~m}$ asl), Quebrada Gon-

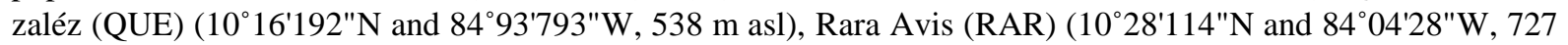
$\mathrm{m}$ asl), and Zurqui (ZUR) (10 $04^{\prime} 854^{\prime \prime} \mathrm{N}$ and $84^{\circ} 01^{\prime} 456 " \mathrm{~W}, 1570 \mathrm{~m}$ asl) (Figure 1). To estimate local population density, in each site we counted all P. elata individuals in a 1600 - 1800 length and 6 m wide plot.

For each flowering plant, we determined the number of flower morphs (thrum or pin) within each sampled plot. The relative difference between the morph frequencies (deviations morphs) was calculated by the formula (Number of short-styled plants-Number of long-styled plants/total flowering plants), as proposed by Brys et al. (2004) [17]. Consequently, the results may vary from 0 (same frequency of both morphs) to 1 (where only one 

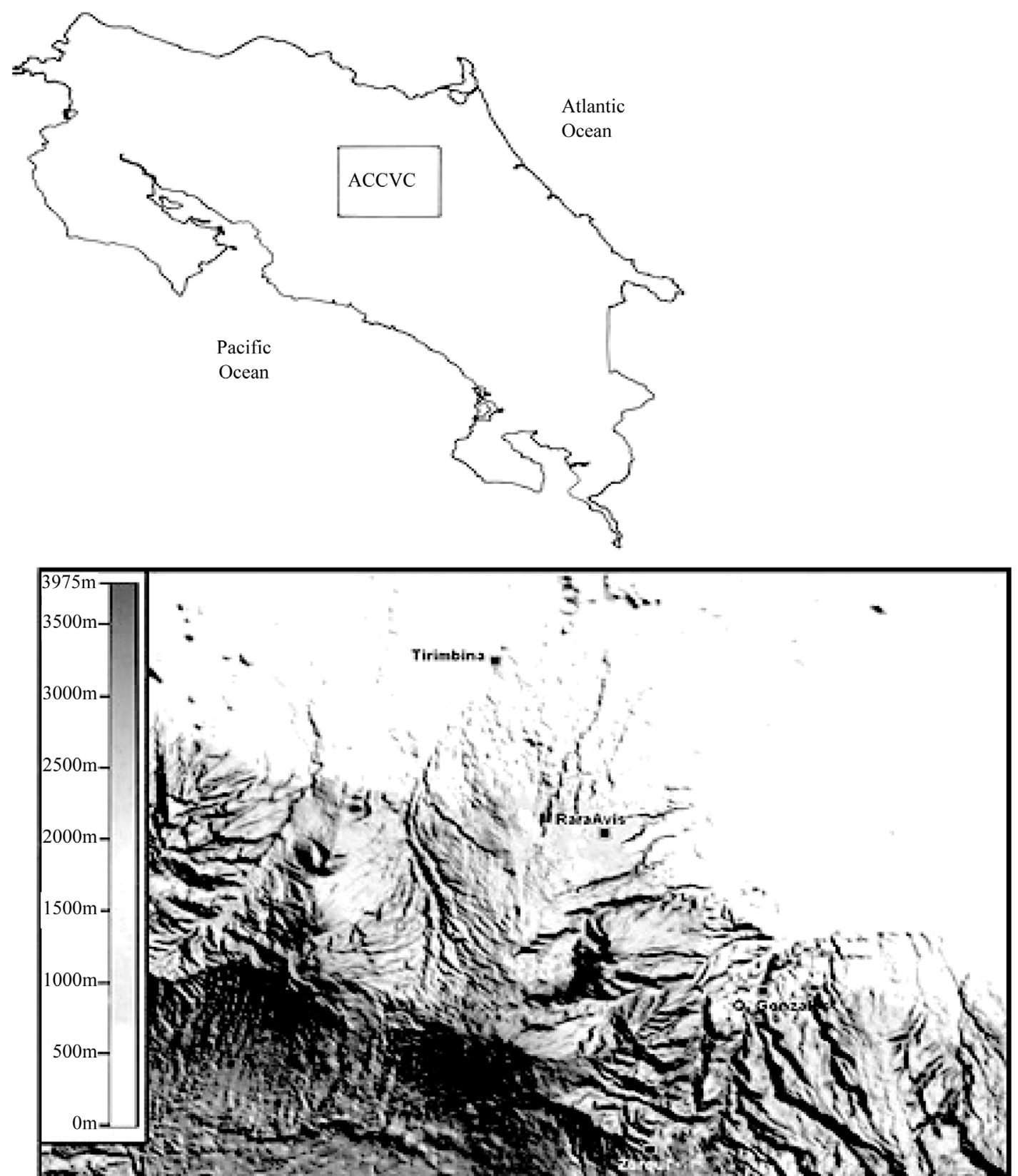

Figure 1. Map of the study areas: Central Volcanic Cordillera Conservation Area of Costa Rica (above). Sites and topography of the study areas, indicating the altitudinal gradient (below).

of the two morphs is present) [17] [18]. Significative differences from an expected 1:1 ratio in each population were tested by a $\mathrm{X}^{2}$ test.

Voucher specimens are deposited in the Herbarium of the Universidad de Costa Rica (UCR) and the Herbarium TANG of the University of Mato Grosso, UNEMAT campus Tangará da Serra, Brazil.

\subsection{Analysis of Reproductive Components of the Species in Each Population}

In each population, in one-or two-week intervals, from January to June 2013, we recorded the number of inflorescences and of open flowers per inflorescence per plant.

To assess the variation in display of $P$. elata inflorescences, the capitulum width (including the lateral bracts) was measured. To assess the mean number of flower/inflorescence per morph, we dissected 5 inflorescences per 
plant of 30 and 22 thrum and pin morph plants, respectively. We avoided sampling of clones, from the same individual, by sampling plants at a distance of at least $3 \mathrm{~m}$ from each other [19].

To estimate pollen viability, 25 thrum and 25 pin buds in pre-anthesis were collected from 10 plants per population and stored in acetic acid. The anthers of each bud were mounted on slides and stained with acetocarmine [20].

The total number of pollen grains per flower was calculated by multiplying the total pollen counts of one anther by the number of anthers per flower $(\mathrm{N}=5)$.

\subsection{Variation in Floral Traits}

The herkogamy of each studied population was characterized by a sample of five flowers of up to five different plants per morph (total number of flowers $=175$ ). Of each fully open flower we measured the corolla length (from base to apex of the lobes), stigma height (measured above the inferior ovary to the apex of the bifurcation) and anthers height (above the inferior ovary to the apex of the anther). Measurements were performed using an Olympus microscope SZX12 equipped with an ocular micrometer of $0.01 \mathrm{~mm}$ at $90 \mathrm{X}$.

The reciprocity between anther and stigma height in the two morphs was determined by the reciprocity index (RI) sensu Richards and Koptur (1993) [21].

$$
\mathrm{RI}=(\mathrm{A}-\mathrm{S}) /(\mathrm{A}+\mathrm{S})
$$

where $\mathrm{A}$ is the mean anther position of the morph and $\mathrm{S}$ the mean stigma position of the alternative morph, when reciprocity is perfect RI $=0$ [22]. Positive values indicate that the mean anther position is higher than the stigma position, while negative values indicate the opposite [23].

\subsection{Reproductive System and Success}

To determine the incompatibility system and reproductive success per morph in each population, the number of seeds per fruit and number of fruits per inflorescence (40 - 50 days after treatments) was evaluated in the following treatments: i) spontaneous self-pollination (bagged flowers when in bud stage, using one to five plants per morph/population) and ii) open pollination (flowers exposed to natural pollination), applied in all populations. The flowers treated with hand and spontaneous self-pollination of both morphs of $P$. elata (total $\mathrm{N}=15$ ) were collected $24 \mathrm{~h}$ after the treatment, fixed in FAA and the pollen tube growth observed by fluorescence microscopy [24] [25].

The reproductive success was estimated by counting the number of fruits per inflorescence and number of seeds per fruit of the inflorescences $(\mathrm{N}=10)$, originating from natural pollination of up to five plants of each morph per population. Early development and abortion of the two ovules were observed in the fruits with no seeds.

\subsection{Floral Visitors}

Floral visitors were observed during the day in the months of March to May 2013 in all populations, except ZUR. Despite several attempts, the pollinators of this population could not be filmed, due to rapid and constant climate variations, posing risks to the filming equipment and safety of the researchers. In the other populations, the identification of flower visitors was performed by filming the flowers and inflorescences of both floral morphs with Sony ${ }^{\circledR}$ digital cameras in about eight hours of footage per day. Aside from filming, additional information was obtained by direct observations.

At every visit, the collected resource and frequency of the visitor were recorded. The visitor frequency per inflorescence/morph was classified as infrequent (1 - 5 visits), frequent (5 - 10 visits), or very frequent (over 10 visits). Visitors that touched the reproductive organs (anthers and stigmas) during the visit were considered pollinators.

\subsection{Statistical Analysis}

Test of differences in the frequency of floral morphs between populations was tested using the chi square test.

One-way analysis of variance (ANOVA) Statistica version 10 [26] was used for the variations in floral traits between populations and the Student $t$ test to check the morphometric variations of flowers and morphs and pol- 
len production and viability between populations. For natural pollination, when significantly different, we performed a post hoc Tukey's HSD test. To improve the normality and homoscedasticity, data of the number of pollen grains were log-transformed before proceeding with the analysis.

\section{Results}

\subsection{Floral Characteristics, Morph Frequency and Herkogamy}

In all populations flowering began in mid-February to early March 2013. Flowering of the floral morphs was synchronous, except in population QUE, where the thrum plants initiated flowering about 30 days after the pin plants. Interestingly, the thrum morph flowers in the RAR population lasted two days, while the pin flowers in the same and other populations lasted one day.

Both floral morphs of $P$. elata were present in the populations studied. Although no monomorphism was detected in any population, the deviations from the 1:1 ratio in the proportions of pin and thrum morphs were variable (Table 1). The highest differences between floral morph ratios were observed in the populations QUE (1Thrum:4Pin, $\chi^{2}=6.38, \mathrm{p}=0.01$ ) and RAR (6.3 Thrum:1Pin; $\chi^{2}=9.40, \mathrm{p}=0.002$ ). The other populations did not differ significantly from the $1: 1$ floral morph ratio in population TIR $\left(\chi^{2}=2.81, \mathrm{p}=0.09\right)$ and ZUR $\left(\chi^{2}=\right.$ 2.92, $\mathrm{p}=0.09$ ).

The inflorescence width ranged from 3.5 to $10 \mathrm{~cm}$ and was similar between morphs in all populations studied. The average number of flowers per inflorescence ranged from 10 to 57 and was significantly higher in thrum morphs of the populations TIR, ZUR and RAR and pin morphs of QUE (Table 1). The number of inflorescences per plant ranged from 1 to 53 and was significantly higher in thrum morphs of RAR, although the number of open flowers per inflorescence/day did not differ statistically between morphs in all populations (Table 1).

The corolla tube length was similar between morphs in the populations TIR $(t=0.186 ; p>0.05)$; $R A R(t=$ 0.150; $p>0.05)$ and ZUR ( $\mathrm{t}=0.71 ; \mathrm{p}>0.05)$, whereas the corolla tube length of the pin morphs in QUE was statistically different $(\mathrm{t}=2.8 ; \mathrm{p}<0.05)$.

The height of stigmas and anther within the thrum and pin morphs was similar in the populations studied, except in ZUR, where the variation in the height of the sexual organ (anther and stigma) in both morphs was greater than in the other populations (Figure 2(a) and Figure 2(b)).

The reciprocity index for both morphs of $P$. elata ranged from 0.00 to 0.08 .

The difference between the stamen (thrum) versus style heigth (pin) and stamens (pin) versus style heigth (thrum) was significantly different in TIR $(\mathrm{F}=19.41 ; \mathrm{p}=0.006$ and $\mathrm{F}=19.41 ; \mathrm{p}=0.0009$, respectively, Figure 3(a) and Figure 3(b)) and ZUR $(F=9.38 ; p=0.004$ and 29.17; $p=0.0001$, respectively, Figure 3(a) and Figure 3(b)). There were no significant differences between the stamen and stigma height of alternative morphs in population RAR ( $F=1.74 ; p=0.19$, and $F=3.33 ; p=0.07$, Figure 3(a) and Figure 3(b)). Interestingly, in population QUE the stamen height of the pin morph was perfectly equal to the stigma height of the thrum morph, i.e., herkogamy is reciprocal ( $\mathrm{F}=0.051 ; \mathrm{P}=0.82$, Figure $3(\mathrm{~b})$ ), but the level of reciprocity was not the same between the stamen height of thrum morph and stigma height of pin morph $(F=50.28 ; p=0.0001$, Figure 3(a)).

In a comparison of the populations, pollen production was significantly lower in the morphs of population

Table 1. Mean and standard deviation of floral characteristics, frequency deviation and morphs between floral morphs Pin and Thrum in natural populations of Psychotria elata the Central Volcanic Cordillera of Costa Rica.

\begin{tabular}{|c|c|c|c|c|c|c|}
\hline Population & Morph frequency & $\begin{array}{l}\text { Inflorescence } \\
\text { length }(\mathrm{cm})\end{array}$ & $\begin{array}{c}\text { No. of inflorescences/ } \\
\text { Plant }\end{array}$ & $\begin{array}{l}\text { No. of flowers/ } \\
\text { inflorescences }\end{array}$ & $\begin{array}{l}\text { No. of open flowers/ } \\
\text { inflorescence/day }\end{array}$ & $\begin{array}{l}\text { Deviations } \\
\text { morphs ratios }\end{array}$ \\
\hline TIR & $\begin{array}{l}\text { Thrum (07) } \\
\text { Pin (04) }\end{array}$ & $\begin{array}{c}5.1 \pm 1.18 \\
4.99 \pm 1.25\end{array}$ & $\begin{array}{c}21.0 \pm 1.55 \\
17.25 \pm 0.41\end{array}$ & $\begin{array}{c}21.2 \pm 7.75^{*} \\
16.2 \pm 5.71\end{array}$ & $\begin{array}{l}1.0 \pm 0.64 \\
0.6 \pm 0.59\end{array}$ & $0.27-$ \\
\hline QUE & $\begin{array}{l}\text { Thrum (04) } \\
\text { Pin (13) }\end{array}$ & $\begin{array}{l}5.58 \pm 1.80 \\
6.25 \pm 1.64\end{array}$ & $\begin{array}{l}28.25 \pm 19.9 \\
15.75 \pm 4.33\end{array}$ & $\begin{array}{c}19.2 \pm 6.57 \\
30.0 \pm 5.69^{*}\end{array}$ & $\begin{array}{c}0.9 \pm 0.31 \\
1.05 \pm 0.68\end{array}$ & $0.50+$ \\
\hline RAR & $\begin{array}{l}\text { Thrum (19) } \\
\text { Pin (03) }\end{array}$ & $\begin{array}{l}5.74 \pm 1.9 \\
4.6 \pm 0.49\end{array}$ & $\begin{array}{l}5.0 \pm 1.73^{*} \\
2.0 \pm 1.41\end{array}$ & $\begin{array}{c}30.76 \pm 8.19^{*} \\
21.2 \pm 3.60\end{array}$ & $\begin{array}{l}1.96 \pm 0.67 \\
1.81 \pm 0.44\end{array}$ & $0.76-$ \\
\hline ZUR & $\begin{array}{l}\text { Thrum (04) } \\
\text { Pin (09) }\end{array}$ & $\begin{array}{l}7.58 \pm 1.09 \\
8.65 \pm 1.69\end{array}$ & $\begin{array}{c}4.5 \pm 1.73 \\
4.61 \pm 3.05\end{array}$ & $\begin{array}{c}41.3 \pm 4.11 \\
50.2 \pm 8.64^{*}\end{array}$ & $\begin{array}{l}1.23 \pm 0.59 \\
1.66 \pm 0.70\end{array}$ & $0.45+$ \\
\hline
\end{tabular}

$+=$ predominance of long-styled plants; $-=$ predominance of short-styled plants; ${ }^{*}$ Morphs differ significantly $(\mathrm{p}<0.005)$ by the Student $t$ test. 


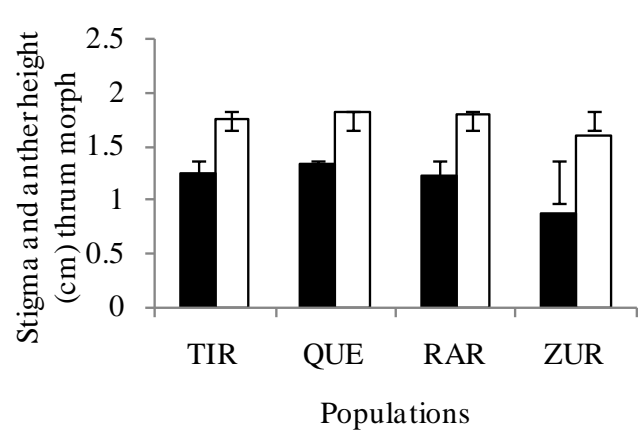

(a)

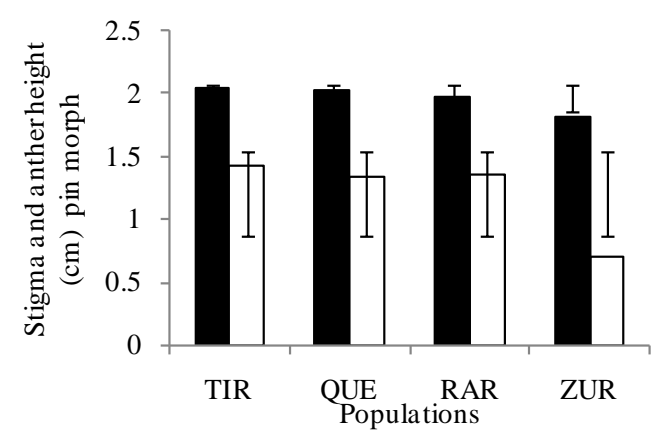

(b)

Figure 2. Herkogamy in four Psychotria elata populations in Central Volcanic Cordillera of Costa Rica. (standard deviation represented by bars); (匹) Stigma, ( $\square$ ) Anther.

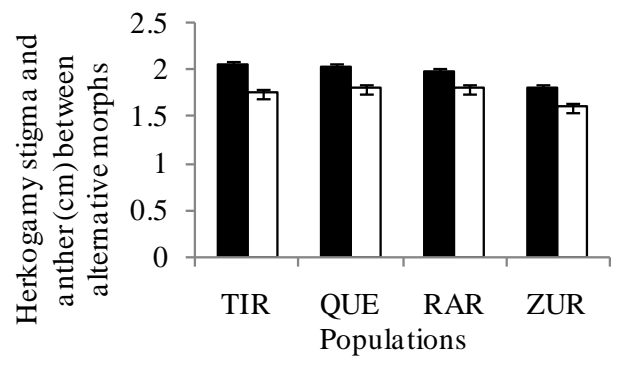

(a)

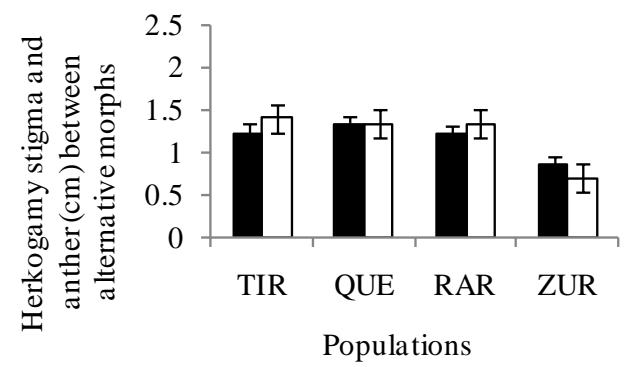

(b)

Figure 3. Difference in herkogamy (mean values) between stigma height ( $\square$ ) Pin vs anther height ( $\square$ ) Thrum (a) and stigma height Thrum (ם) vs anther height ( $\square$ ) Pin (b) in Psychotria elata populations in the Central Volcanic Cordillera of Costa Rica.

TIR ( $\mathrm{F}=27.70 ; \mathrm{p}=0.002)$ Table 2 . The average pollen production per morph and population was highly variable, and pollen viability was high (>90\%) in all populations and similar between morphs (Table 2).

\subsection{Reproductive System}

A breakdown of incompatibility was observed in Psychotria elata in TIR thrum morphs and RAR pin morphs, confirmed by the treatment of spontaneous hand self-pollination (Table 3) and growth of the pollen tube to the stylus base in both treatments. The fruiting percentages resulting from natural pollination varied from $7.77 \%$ to $27.54 \%$ for pin morphs and from $7.82 \%$ to $33.49 \%$ for thrum morphs. The percentage of fruits produced by flower from natural pollination in population TIR was significantly greater from QUE and RAR (Table 3) and may be overestimated, since many of these seeds may have resulted from spontaneous self-pollination.

The number of fruits and seeds of each floral morph in the studied populations are listed in Table 4. The mean fruit productions per individual and per inflorescence were higher in thrum than in pin morphs in the populations TIR (mean thrum $=47.33 \pm 29.73$ vs. pin $30.66 \pm 35.94$; and thrum $7.1 \pm 4.05$ vs pin. $4.60 \pm 5.6$, respectively); ZUR (mean thrum $43.33 \pm 47.72$ vs. pin $29.66 \pm 28.14$; and thrum $9.76 \pm 10.4$ vs pin $5.31 \pm 7.77$, respectively); QUE (mean thrum $22.5 \pm 7.77$ vs. pin $9.5 \pm 9.19$; and thrum $2.23 \pm 2.14$ vs. pin $1.9 \pm 1.44$, respectively). The fruit production per individual from the thrum morphs of population RAR was five times higher than from the pin morph (mean thrum $45.00 \pm 32.22$ vs. pin $9.5 \pm 5.5$ ) whereas the number of fruits per inflorescence was similar between the morphs (thrum $3.48 \pm 4.58$ and pin $3.8 \pm 1.30$ ). One-seeded fruits had normal development, however with the presence of a single embryo. In the populations TIR and ZUR, total seed production was not higher in the morph with greater frequency (thrum and pin, respectively, Table 1). These populations, where the morph ratio was $\leq 0.45$ (Table 1 ) were those that produced seedless fruits. The populations QUE and RAR, with a morph ratio of $\geq 0.5$ (Table 1), produced the highest percentage of fruits with two seeds (Table 4). 
Table 2. Pollen production and viability in thrum and pin morph flowers of Psychotria elata in the Central Volcanic Cordillera of Costa Rica.

\begin{tabular}{|c|c|c|c|c|c|c|c|c|}
\hline \multirow{2}{*}{$\begin{array}{l}\text { Population } \\
\text { morph }\end{array}$} & \multicolumn{2}{|c|}{ TIR } & \multicolumn{2}{|c|}{ QUE } & \multicolumn{2}{|c|}{ RAR } & \multicolumn{2}{|c|}{ ZUR } \\
\hline & Thrum & Pin & Thrum & Pin & Thrum & Pin & Thrum & Pin \\
\hline $\begin{array}{c}\text { Pollen } \\
\text { production }\end{array}$ & ${ }^{*} 414 \pm 297.7$ & $1771 \pm 570.2$ & $2091 \pm 259.2$ & $2613 \pm 679.8$ & $2981 \pm 255.1$ & $2930 \pm 1855.5$ & $1233 \pm 870.6$ & $2386 \pm 375.5$ \\
\hline $\begin{array}{c}\text { Pollen } \\
\text { viability (\%) }\end{array}$ & $97.6 \pm 2.8$ & $98 \pm 5.2$ & $95.2 \pm 5.1$ & $97.9 \pm 2.5$ & $99.5 \pm 1.7$ & $99.5 \pm 1.9$ & $97.2 \pm 1.5$ & $98.9 \pm 5.2$ \\
\hline
\end{tabular}

* Morphs differ significantly $(\mathrm{p}<0.005)$ by the Student $\mathrm{t}$ test.

Table 3. Mating system in natural Psychotria elata populations in the Central Volcanic Cordillera of Costa Rica.

\begin{tabular}{|c|c|c|c|c|}
\hline Treatment & Population & Morph floral & $\begin{array}{c}\text { Number of } \\
\text { inflorescences }\end{array}$ & $\begin{array}{l}\text { Fruits/flowers } \\
\text { (\% frutification) }\end{array}$ \\
\hline \multirow[t]{4}{*}{ Spontaneous self-pollination } & TIR & $\begin{array}{l}\text { Thrum } \\
\text { Pin }\end{array}$ & $\begin{array}{l}4 \\
4\end{array}$ & $\begin{array}{c}12 / 85(14.11) \\
0 / 65(0.00)\end{array}$ \\
\hline & QUE & $\begin{array}{l}\text { Thrum } \\
\text { Pin }\end{array}$ & $\begin{array}{l}5 \\
6\end{array}$ & $\begin{array}{c}0 / 96(0.00) \\
0 / 180(0.00)\end{array}$ \\
\hline & RAR & $\begin{array}{l}\text { Thrum } \\
\text { Pin }\end{array}$ & $\begin{array}{l}5 \\
3\end{array}$ & $\begin{array}{c}0 / 154(0.00) \\
0 / 64(0.00)\end{array}$ \\
\hline & ZUR & $\begin{array}{l}\text { Thrum } \\
\text { Pin }\end{array}$ & $\begin{array}{l}5 \\
6\end{array}$ & $\begin{array}{l}0 / 206(0.00) \\
0 / 301(0.00)\end{array}$ \\
\hline \multirow[t]{4}{*}{ Hand self-pollination } & TIR & $\begin{array}{l}\text { Thrum } \\
\text { Pin }\end{array}$ & $\begin{array}{l}4 \\
4\end{array}$ & $\begin{array}{c}6 / 12(50.00) \\
0 / 8(0.00)\end{array}$ \\
\hline & QUE & $\begin{array}{l}\text { Thrum } \\
\text { Pin }\end{array}$ & $\begin{array}{l}4 \\
6\end{array}$ & $\begin{array}{c}0 / 8(0.00) \\
0 / 12(0.00)\end{array}$ \\
\hline & RAR & $\begin{array}{l}\text { Thrum } \\
\text { Pin }\end{array}$ & $\begin{array}{l}5 \\
2\end{array}$ & $\begin{array}{c}0 / 16(0.00) \\
4 / 6(66.6)\end{array}$ \\
\hline & ZUR & $\begin{array}{l}\text { Thrum } \\
\text { Pin }\end{array}$ & $\begin{array}{l}5 \\
7\end{array}$ & $\begin{array}{l}0 / 5(0.00) \\
0 / 7(0.00)\end{array}$ \\
\hline \multirow[t]{4}{*}{ Natural pollination } & TIR & $\begin{array}{l}\text { Thrum } \\
\text { Pin }\end{array}$ & $\begin{array}{l}20 \\
20\end{array}$ & $\begin{array}{c}142 / 424(33.49) \mathrm{a} \\
92 / 334(27.54)\end{array}$ \\
\hline & QUE & $\begin{array}{l}\text { Thrum } \\
\text { Pin }\end{array}$ & $\begin{array}{l}6 \\
6\end{array}$ & $\begin{array}{c}09 / 115 \text { (7.82) bc } \\
14 / 180(7.77)\end{array}$ \\
\hline & RAR & $\begin{array}{l}\text { Thrum } \\
\text { Pin }\end{array}$ & $\begin{array}{l}5 \\
4\end{array}$ & $\begin{array}{c}17 / 154(11.03) \text { c } \\
21 / 85(24.70)\end{array}$ \\
\hline & ZUR & $\begin{array}{l}\text { Thrum } \\
\text { Pin }\end{array}$ & $\begin{array}{c}13 \\
7\end{array}$ & $\begin{array}{c}130 / 533 \text { (24.39) ab } \\
89 / 355 \text { (25.07) }\end{array}$ \\
\hline
\end{tabular}

Number of flowers of spontaneous self pollination and the control were obtained from the average number of flowers per inflorescence per morph in the population, multiplied by the number of treated inflorescences/morph per population. Significant differences $(p<0.05)$ were indicated by letters. Same letters indicates no significant difference between populations by the Tukey test.

\subsection{Floral Visitors}

In the populations studied, the different guilds of visitors observed in 106 hours of footage were represented by hummingbirds the families Trochilidae, butterflies of the families Nymphalidae, Ridiononidae and bees (family Apidae) (Table 5). Chalybura urochrysia was the only hummingbird visitor in all populations.

The visiting behavior of Phaethornis striigularis differed between the populations TIR and QUE. In the first, this hummingbird served as pollinator, but in the second as nectar thief, because it stole the nectar without inserting the beak into the corolla tube. Although in different frequencies Hyposcada virginiana evanides (Nymphalidae) and Eurybia lycisca (Riodinidae) were observed in all populations, whereas Euglosa sp. (Apidae) were observed onlyin TIR and RAR (Table 5). The thrum morph was preferred by the visitors in TIR (78\%) and RAR (92\%). In the population QUE most visitations (76\%) were recorded to the pin morph. 
Table 4. Reproductive success in natural populations of Psychotria elata in the Central Volcanic Cordillera of Costa Rica.

\begin{tabular}{|c|c|c|c|c|c|c|c|}
\hline \multirow{2}{*}{$\begin{array}{l}\text { Populations/ } \\
\text { Morphs }\end{array}$} & \multirow{2}{*}{$\begin{array}{l}\text { Counted number } \\
\text { of fruits }\end{array}$} & \multirow{2}{*}{$\begin{array}{c}\text { Mean } \pm \text { standard } \\
\text { seeds/inflorescence }\end{array}$} & \multicolumn{3}{|c|}{$\%$ seeds/fruit } & \multirow{2}{*}{$\begin{array}{l}\text { Total number } \\
\text { of seeds/morph }\end{array}$} & \multirow{2}{*}{$\begin{array}{l}\text { Mean } \pm \text { standarc } \\
\text { deviation/morph }\end{array}$} \\
\hline & & & 0 & 1 & 2 & & \\
\hline TIR/ & 142 & $12.84 \pm 9.19$ & 9.15 & 45.07 & 45.77 & 207 & $69.00 \pm 58.6$ \\
\hline Thrum Pin & 184 & $14.41 \pm 7.07$ & 2.17 & 20.65 & 77.17 & 326 & $61.33 \pm 71.89$ \\
\hline QUE/ & 39 & $1.5 \pm 0.02$ & 0.00 & 7.70 & 92.30 & 75 & $17.7 \pm 14.5$ \\
\hline Thrum Pin & 75 & $3.63 \pm 5.65$ & 0.00 & 25.49 & 74.60 & 133 & $36.5 \pm 19.5$ \\
\hline RAR/ & 90 & $6.75 \pm 2.82$ & 0.00 & 14.44 & 85.55 & 167 & $78.5 \pm 65.5$ \\
\hline Thrum Pin & 19 & $5.6 \pm 7.07$ & 0.00 & 21.05 & 78.94 & 34 & $17.0 \pm 13.0$ \\
\hline ZUR/ & 130 & $10.07 \pm 1.41$ & 8.00 & 75.0 & 16.92 & 152 & $50.6 \pm 44.3$ \\
\hline Thrum Pin & 89 & $10.26 \pm 3.53$ & 0.00 & 37.07 & 62.92 & 145 & $48.33 \pm 57.5$ \\
\hline
\end{tabular}

Table 5. Floral visitors in natural populations Psychotria elata in the Central Volcanic Cordillera of Costa Rica.

\begin{tabular}{|c|c|c|c|c|c|}
\hline Family & Species & TIR & $\begin{array}{c}\text { Populations } \\
\text { QUE }\end{array}$ & RAR & $\begin{array}{c}\text { Collected } \\
\text { resource }\end{array}$ \\
\hline \multirow[t]{3}{*}{ Trochilidae } & Chalybura urochrysia & ++ & +++ & ++ & Nectar \\
\hline & Phaethornis striigularis & ++ & ++ & - & Nectar \\
\hline & Hyposcada virginiana evanides & ++ & ++ & ++ & Nectar \\
\hline \multirow[t]{2}{*}{ Nymphalidae } & Heliconius cydnogalanthus & - & - & ++ & Nectar \\
\hline & Heliconius doris & ++ & - & - & Nectar \\
\hline Riodinidae & Eurybia lycisca & ++ & + & ++ & Nectar \\
\hline \multirow[t]{2}{*}{ Apidae } & Euglosa sp & - & - & + & Pollen \\
\hline & Euglosa sp. 2 & + & - & - & Pollen \\
\hline Hours of footage & & 40 & 46 & 20 & \\
\hline
\end{tabular}

$+++=$ very frequent; $++=$ frequent; $+=$ infrequent.

\section{Discussion}

This study demonstrated that the frequency of floral morphs varies considerably within populations. All populations of P. elata showed deviations from 1:1 morph ratio (anisoplethy), which be related to the breakdown of the heteromorphic incompatibility system, differences in reproductive success and stochastic processes; the latter especially in populations QUE and RAR.

By definition, herkogamy in a distylous taxon expresses the reciprocal heigth of anthers and stigma in flowers of different morphs [27]. This characteristic has been considered an essential component in explanatory models of evolution and maintenance of heterostyly [2] [4]. As the stamens are epipetalous, reciprocal herkogamy should be established by variations in stigma height according to the corolla length and the absolute value of the difference between anther and stigma heights should be identical between floral morphs [28]. These assumptions were partially confirmed in this study for P. elata.

It is reasonable to assume that reciprocal herkogamy of stigma and anthers between alternative floral morphs promote pollen transfer of functionally equivalent amounts from one morph to another [21] [28]. In this sense, it would be expected that reciprocal herkogamy in population QUE increased female fitness of the thrum morph and male fitness of the pin morph as pollen donor. However, it was found that the percentages of fruiting from natural pollination of both morphs were similar in this population. In populations in which stamen and pistil lengths differed significantly between alternative morphs (TIR and ZUR), the rate of natural fruit set and total number of seeds produced by both morphs was also similar.

Our results suggest that reciprocal herkogamy should not be seen as the only factor affecting the reproductive success of distylous species. The varied degree of herkogamy at different levels (species, populations and plants within population) reveals that multiple factors (genetic, pollinators, reproductive system, plant architecture, and perianth shape) determine the significance of this strategy [29].

Within a same species, the degree of herkogamy can vary substantially, and these differences can in turn con- 
tribute to varying levels of autonomous self-pollination for total seed set [30].

Ganders (1979) [31] found that differences of less than $2 \mathrm{~mm}$ between stigma and anther height in pin flowers of Lithospermum californicum (Boraginaceae) affected the degree of inter-morph pollination significantly, but not the stability of distyly. Different levels of stigma height and anther length have been reported in other distylous species such as Psychotria ternifolia [29], Hediotys caeruela [32] and Narcissus assoanus [33].

The population data clearly indicate specific differences in the mating system between thrum and pin morphs and suggest that natural conditions may cause variation in the proportion of floral morphs of P. elata. To the morph thrum of RAR, an anthesis of 48 hours, coupled with the highest number of flowers/inflorescence and a high percentage of visitation, promoted an asymmetrical pollen flow between floral morphs, resulting in higher fruit and seed production.

Although the frequency of thrum and pin morphs was not very different in population TIR, a breakdown of the heteromorphic self-incompatibility was observed. This result can be explained by the high number of flowers per inflorescence, high visitation preference, low pollen production, and a shift in the morph frequency should not be seen as the only factors promoting the breakdown of self-incompatibility. Fruit formation in hand pollination treatments in RAR pin morphs may be a strategy of colonization of new areas and reduced anisoplethy in that population. A reduction in the number of seeds can cause selection of floral traits and mating strategies that will ensure seed production by a system of self-pollination [34].

Lower rates of total seed production were recorded in populations with larger intramorph deviations (QUE and RAR), suggesting increased pollen limitation in small $P$. elata populations. This reproductive difference between morphs tends to decrease in populations such as TIR and ZUR, with more balanced morph ratios. Studies indicated a reduction in reproductive success in populations with large deviations (over 50\%) in the frequency of floral morphs [35].

Similar patterns were observed in distylous populations of Primula vulgaris, i.e., the population size can have a negative effect on the reproductive success if the morph frequency is significantly large [17]. Models of evolution and maintenance of stigma height in dimorphic populations of Narcissus sp. demonstrated that most matings in isoplethic populations are not random, and that this possibility of mating is reduced in anisoplethic populations [36].

In a study of the reproductive biology of 21 species of Psychotria on Barro Colorado Island, Sakai and Wright (2008) [37] compared data from phylogenetic information of the genus, and found that changes in the morphological characteristics of distyly are associated with the weakening of incompatibility, and monomorphism and homostyly that evolved independently in the genus as a result of low population density and limited availability of pollen. Pollen limitation has been related to the formation of one-seeded fruits in distylous species of Palicourea [38] and Psychotria [20] [39]. The formation of seedless fruits was recorded in Palicourea lassiolaris [40] and P. longepedunculata [38].

Inflorescences of $P$. elata have two red lateral bracts, which may increase the attractiveness to pollinators. The inflorescence size plus the number of inflorescences per plant and the number of open flowers/inflorescence/day increase the floral display and can be critical to the reproductive success of the floral morphs of $P$. elata.

The pollinators recorded in P. elata populations have been commonly reported in other Psychotria species, hummingbirds [41] [42], butterflies [43], moths [44], and bees [37] [45].

The visitation preference for only one of the morphs of $P$. elata can be partly explained by the unbalanced ratio of these morphs in populations. For example, in population RAR the only three pin plants had one to four inflorescences each, which in open pollination would be less attractive to pollinators than the display of the 19 thrum plants in that population. Interestingly, despite the presence of pollinators, visitations were not very frequent in this population. The low frequency of these pollinators may be due to the high rainfall in this study area (average of $7000 \mathrm{~mm} /$ year, Amos Bien, personal communication).

Aside from the reciprocity between reproductive organs in distylous species, the pollinator efficiency is also considered a guarantee that pollen from a floral morph is deposited on the pollinator's body corresponding to the position of the stigma of the alternative floral morph [28].

Studies have shown that hummingbirds can be more efficient pollinators than butterflies and moths in distylous Psychotria species. In a study about the variation of heterostyly in three Rubiaceae species, Faivre and McDade 2001 [28] showed that, unlike the hummingbirds, the very narrow proboscis of butterflies and moths may have an effect on the precise positioning of pollen deposition and transfer in relation to the position of the 
floral structures. Short-tongued insects feed on pollen from the stamens in the upper part of the floral tube and may not be able to achieve the sexual organs at a lower level [46] [47]), which may alter the patterns of legitimate pollen transfer between populations [48]. However, the low efficiency of short-tongued insects can be overcome by the low frequency of these visitors in natural $P$. elata populations.

\section{Conclusion}

All studied populations of $P$. elata are distylous and anisoplethic. The absence of reciprocal herkogamy between floral morphs led to a wide variation in number of fruits and seeds between morphs and among populations. Hummingbirds, butterflies and bees were the main visitors of $P$. elata flowers.

\section{Acknowledgements}

The authors gratefully acknowledge the suggestions of two anonymous reviewers. They are indebted to the National Council for Scientific and Technological Development—CNPq for granting a scholarship for post doctoral studies Abroad (PDE) and to the program Science Without Borders (Grant No. 237484/2012-9), to the National System of Conservation Areas of Costa Rica (SINAC), for authorizing our surveys in the Central Volcanic Cordillera Conservation Area, to the administration of the reserves of Rara Avis and Tirimbina for the permission to carry out field work.

\section{References}

[1] Barrett, S.C.H. (2002) The Evolution of Plant Sexual Diversity. Nature Reviews Genetic, 3, 274-284. http://dx.doi.org/10.1038/nrg776

[2] Lloyd, D.G. and Webb, C.J. (1992) The Selection of Heterostyly. In: Barrett, S.C.H., Ed., Evolution and Function of Heterostyly, Springer-Verlag, Berlin, 179-207. http://dx.doi.org/10.1007/978-3-642-86656-2_7

[3] Lewis, D. and Jones, D.A. (1992) The Genetics of Heterostyly. In: Barrett, S.C.H., Ed., Evolution and Function of Heterostyly, Springer-Verlag, Berlin, 129-130. http://dx.doi.org/10.1007/978-3-642-86656-2_5

[4] Charlesworth, D. and Charlesworth, B. (1979) A Model for Evolution of Heterostyly. American Naturalist, 114, 467498. http://dx.doi.org/10.1086/283496

[5] Weller, S.G., Domínguez, C.A., Molina-Freaner, F.E., Foroni, J. and Le Buhn, G. (2007) The Evolution of Distyly from Tristyly in Populations of Oxalis alpina (Oxalidaceae) in the Sky Islands of the Sonoran Desert. American Journal of Botany, 94, 972-985. http://www.amjbot.org/content/94/6/972.full.pdf+html http://dx.doi.org/10.3732/ajb.94.6.972

[6] Pérez-Barrales, R., Arroyo, J. and Armbruster, W.S. (2007) Differences in Pollinator Faunas May Generate Geographic Differences in Floral Morphology and Integration in Narcissus papyraceus (Amaryllidaceae). Oikos, 116, 1904-1918. http://dx.doi.org/10.1111/j.0030-1299.2007.15994.x

[7] Pérez-Barrales, R. and Arroyo, J. (2010) Pollinator Shifts and the Loss of Style Polymorphism in Narcissus papyraceus (Amaryllidaceae). Journal Evolution Biology, 23, 1117-1128. http://dx.doi.org/10.1111/j.1420-9101.2010.01988.x

[8] Barrett, S.C.H., Harder, L.D. and Cole, W. (2004) Correlated Evolution of Floral Morphology and Mating-Type Frequencies in a Sexually Polymorphic Plant. Evolution, 58, 964-975. http://www.jstor.org/discover/10.2307/3449192 http://dx.doi.org/10.1111/j.0014-3820.2004.tb00431.x

[9] Hodgins, K.A. and Barrett, S.C.H. (2008) Geographical Variation and Style-Morph Rtios in a Sexually Polymorphic Daffodil. American Journal of Botany, 95, 185-195. http://www.amjbot.org/10.3732/ajb.95.2.185 http://dx.doi.org/10.3732/ajb.95.2.185

[10] Hodgins, K.A. and Barrett, S.C.H. (2006) Female Reproductive Success and the Evolution of Mating-Type Fequencies in Tristylous Populations. New Phytologist, 171, 569-580. http://onlinelibrary.wiley.com/doi/10.1111/j.1469-8137.2006.01800.x

[11] Schvinn, T.A., Miranda, A.F. and Silva, C.A. (2014) Reproductive Biology of Amasonia obovata Gleason (Laminaceae). Acta Amazonica, 44, 427-434.

[12] Dart, S.R., Samir, K.E., Austen, E. and Eckert, C.G. (2012) Broad Geographic Covariation between Floral Traits and the Mating System in Camissoniopsis cheiranthifolia (Onagraceae): Multiple Stable Mixed Mating Systems across the Species Range? Annals of Botany, 109, 599-611. http://dx.doi.org/10.1093/aob/mcr266

[13] Brunet, J. and Eckert, C.G. (1998) Effects of Floral Morphology and Display on Outcrossing in Blue Columbine, Aquilegia caerulea (Ranunculaceae). Functional Ecology, 12, 596-606. 
http://dx.doi.org/10.1046/j.1365-2435.1998.00231.x

[14] Herlihy, C.R. and Eckert, C.G. (2007) Evolutionary Analysis of a Key Floral Trait in Aquilegia canadensis (Ranunculaceae): Genetic Variation in Herkogamy and Its Effect on the Mating System. Evolution, 61, 1661-1674. http://dx.doi.org/10.1111/j.1558-5646.2007.00137.x

[15] Gargiullo, M.B., Magnuson, B. and Kinball, L. (2008) A Field Guide to Plants of Costa Rica. Zona Tropical Publication, Oxford.

[16] Burger, W. and Taylor, C.M. (1993) Family \#202 Rubiaceae. In: Burger, W., Ed., Flora Costaricensis, Field Museum of Natural History, Chicago.

[17] Brys, R., Jacquemyn, H., Endels, P., Van Rossum, F., Hermy, M., Triest, L., Bruyn, L. and Blust, G.D.E. (2004) Reduced Reproductive Success in Small Populations of the Self-Incompatible Primula vulgaris. Journal of Ecology, 92, 5-14.

[18] Brys, R., Jacquemyn, H. and Beeckman, T. (2008) Morph-Ratio Variation, Population Size and Female Reproductive Success in Distylous Pulmonaria officinalis (Boraginaceae). Journal of Evolutionary Biology, 21, 1281-1289. http://dx.doi.org/10.1111/j.1420-9101.2008.01569.x

[19] Kock, A.K., Silva, P.C. and Silva, C.A. (2010) Biologia Reprodutiva de Psychotria carthagenensis (Rubiaceae), Espécie Distílica de Fragmento Florestal de Mata Ciliar, Centro-Oeste do Brasil. Rodriguésia, 61, 551-558.

[20] Radford, A.E., Dickson, W.C., Massey, J.R. and Bell, C.R. (1974) Vascular Plant Systematics. Harper and Row, New York.

[21] Richards, J.H. and Koptur, S. (1993) Floral Variation and Distyly in Guettarda scabra (Rubiaceae). American Journal of Botany, 80, 31-40. http://dx.doi.org/10.2307/2445117

[22] Massinga, P.H., Johnson, S.D. and Harder, L.D. (2005) Heteromorphic Incompatibility and Efficiency of Pollination in Two Distylous Pentanisia Species (Rubiaceae). Annals of Botany, 95, 389-399. http://dx.doi.org/10.1093/aob/mci040

[23] Keller, B., Vos, J.M. and Cont, E. (2012) Decrease of Sexual Organ Reciprocity between Heterostylous Primrose Species, with Possible Functional and Evolutionary Implications. Annals of Botany, 110, 1233-1244. http://dx.doi.org/10.1093/aob/mcs199

[24] Martin, F.W. (1959) Staining and Observing Pollen Tubes in the Style by Means of Fluorescence. Biotechnic \& Histochemistry, 34, 125-128.

[25] Kearns, C.A. and Inouye, D.W. (1993) Techniques for Pollination Biologists. University Press of Colorado, Niwot.

[26] StatSoft, Inc. (2010) STATISTICS: Methods and Applications. StatSoft, Tulsa.

[27] Barrett, S.C.H. (1990) The Evolution and Adaptive Significance of Heterostyly. Trends in Ecology and Evolution, 5, 144-148. http://dx.doi.org/10.1016/0169-5347(90)90220-8

[28] Faivre, A.E. and Mc Dade, L.A. (2001) Population-Level Variation in the Expression of Heterostyly in Three Species of Rubiaceae: Does Reciprocal Placement of Anthers and Stigmas Characterize Heterostyly? American Journal of Botany, 88, 841-853. http://dx.doi.org/10.2307/2657036

[29] Webb, C.J. and Lloyd, D.G. (1986) The Avoidance of Interference between the Presentation of Pollen and Stigmas in Angiosperms II. Herkogamy. New Zealand Journal of Botany, 24, 163-178. http://dx.doi.org/10.1080/0028825X.1986.10409726

[30] Brys, R. and Jacquemyn, H. (2011) Variation in the Functioning of Autonomous Self-Pollination, Pollinator Services and Floral Traits in Three Centaurium Species. Annals of Botany, 107, 917-925. http://dx.doi.org/10.1093/aob/mcr032

[31] Ganders, F.R. (1979) The Biology of Heterostyly. New Zealand Journal of Botany, 17, 607-635. http://dx.doi.org/10.1080/0028825X.1979.10432574

[32] Sampson, D.A. and Krebs, R.A. (2012) Quantitative Evaluation of Reciprocal Herkogamy in the Distylous Species, Hedyotis caerulea (Rubiaeceae). Plant Systematics and Evolution, 298, 1361-1370. http://dx.doi.org/10.1007/s00606-012-0642-4

[33] Thompson, J.D., Cesaro, A. and Arroyo, J. (2012) Morph Ratio Variation and Sex Organ Reciprocity in Style-Dimorphic Narcissus assoanus. International Journal of Plant Sciences, 173, 885-893. http://dx.doi.org/10.1086/667231

[34] Morgan, M.T. and Wilson, W.G. (2005) Self-Fertilization and the Escape from Pollen Limitation in Variable Pollination Environments. Evolution, 59, 1143-1148. http://dx.doi.org/10.1111/j.0014-3820.2005.tb01050.x

[35] Byers, D.L. and Meagher, T.R. (1992) Mate Availability in Small Populations of Plant-Species with Homomorphic Sporophytic Self-Incompatibility. Heredity, 68, 353-359. http://dx.doi.org/10.1038/hdy.1992.50

[36] Baker, A.M., Thompson, J.D. and Barrett, S.C.H. (2000) Evolution and Maintenance of Stigma-Height Dimorphism in Narcissus. I. Floral Variation and Style-Morph Ratios. Heredity, 84, 502-513. 
http://dx.doi.org/10.1046/j.1365-2540.2000.00651.x

[37] Sakai, S. and Wright, S.J. (2008) Reproductive Ecology of 21 Coexisting Psychotria Species (Rubiaceae): When Is Heterostyly Lost? Biological Journal of the Linnean Society, 93, 125-134. http://dx.doi.org/10.1111/j.1095-8312.2007.00890.x

[38] Silva, C.A., Vieira, M.F. and Amaral, C.H. (2010) Floral Attributes, Ornithophily and Reproductive Success of Palicourea longepedunculata (Rubiaceae), a Distylous Shrub in Southeastern Brazil. Revista Brasileira de Botânica, 33, 207-213.

[39] Silva, C.A. and Vieira, M.F. (2013) Sucesso Reprodutivo de Espécies Distílicas de Psychotria (Rubiaceae) em Sub-bosque de Floresta Atlântica. Revista Árvore, 37, 289-297. http://dx.doi.org/10.1590/S0100-67622013000200010

[40] Feinsinger, P., Busby, W., Murray, K.G., Beach, J.H., Pounds, W.Z. and Linhart, Y.B. (1988) Mixed Support for Spatial Heterogeneity in Species Interactions: Hummingbirds in a Tropical Disturbance Mosaic. American Naturalist, 131, 33-57. http://dx.doi.org/10.1086/284772

[41] Castro, C.C. and Araujo, C.A. (2004) Distyly and Sequential Pollinators of Psychotria nuda (Rubiaceae) in the Atlantic Rain Forest, Brazil. Plant Systematics and Evolution, 244, 131-139. http://dx.doi.org/10.1007/s00606-003-0036-8

[42] Coelho, C.P. and Barbosa, A.A. (2003) Biologia Reprodutiva de Palicourea macrobotrys Ruiz \& Pavon (Rubiaceae): Um Possível Caso de Homostilia no Gênero Palicourea Aubl. Revista Brasileira de Botânica, 26, 403-413.

[43] Watanabe, K., Shimizu, A. and Sugawara, T. (2014) Dioecy Derived from Distyly and Pollination in Psychotria rubra (Rubiaceae) Occurring in the Ryukyu Islands, Japan. Plant Species Biology, 29, 181-191.

[44] Consolaro, H., Toledo, R.D.P., Ferreguti, R.L., Hay, J. and Oliveira, P.E. (2009) Distilia e Homostilia em Espécies de Palicourea Aubl. (Rubiaceae) do Cerrado do Brasil Central. Revista Brasileira de Botânica, 32, 677-689.

[45] Ramos, F.N. and Santos, F.A.M. (2006) Floral Visitors and Pollination of Psychotria tenuinervis (Rubiaceae): Distance from the Anthropogenic and Natural Edges of an Atlantic Forest Fragment. Biotropica, 38, 383-389. http://dx.doi.org/10.1111/j.1744-7429.2006.00152.x

[46] Barrett, S.C.H., Jesson, L.K. and Baker, A.M. (2000) The Evolution and Function of Stylar Polymorphisms in Flowering Plants. Annals of Botany, 85, 253-265. http://dx.doi.org/10.1006/anbo.1999.1067

[47] Alves dos Santos, I. (2002) Flower-Visiting Bees and the Breakdown of the Tristylous Breeding System of Eichhornia azurea (Swartz) Kunth (Pontederiaceae). Biological Journal of the Linnean Society, 77, 499-507. http://dx.doi.org/10.1046/j.1095-8312.2002.00122.x

[48] Alves dos Santos, I. and Wittmann, D. (2000) Legitimate Pollination of the Trimorphic Flowers of Eichhornia azurea (Pontederiaceae) by Ancyloscelis gigas Bees (Anthophoridae, Apoidae). Plant Systematics and Evolution, 223, 127137. http://dx.doi.org/10.1007/BF00985274 
Scientific Research Publishing (SCIRP) is one of the largest Open Access journal publishers. It is currently publishing more than 200 open access, online, peer-reviewed journals covering a wide range of academic disciplines. SCIRP serves the worldwide academic communities and contributes to the progress and application of science with its publication.

Other selected journals from SCIRP are listed as below. Submit your manuscript to us via either submit@scirp.org or Online Submission Portal.
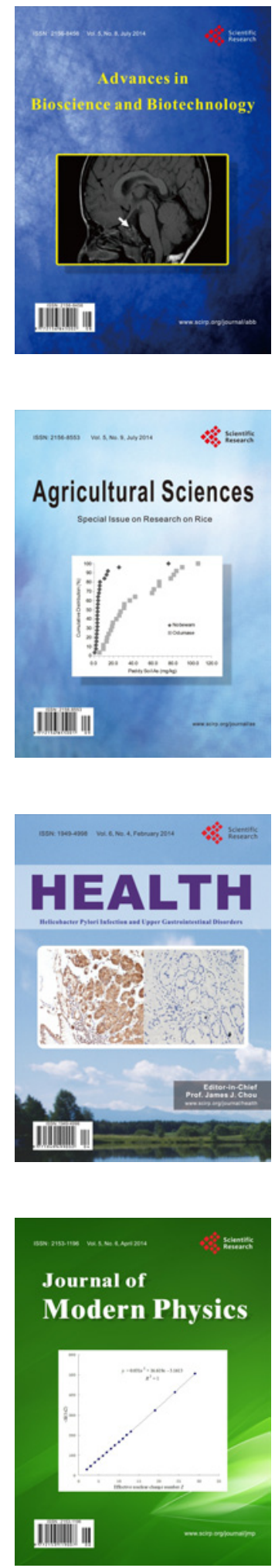
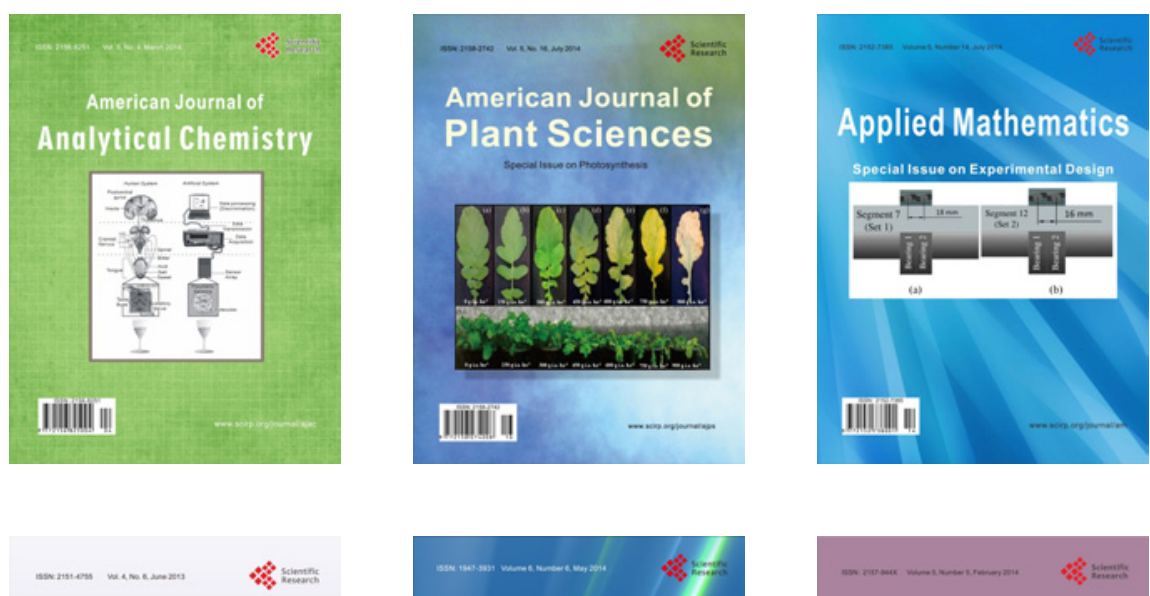

Creative Education
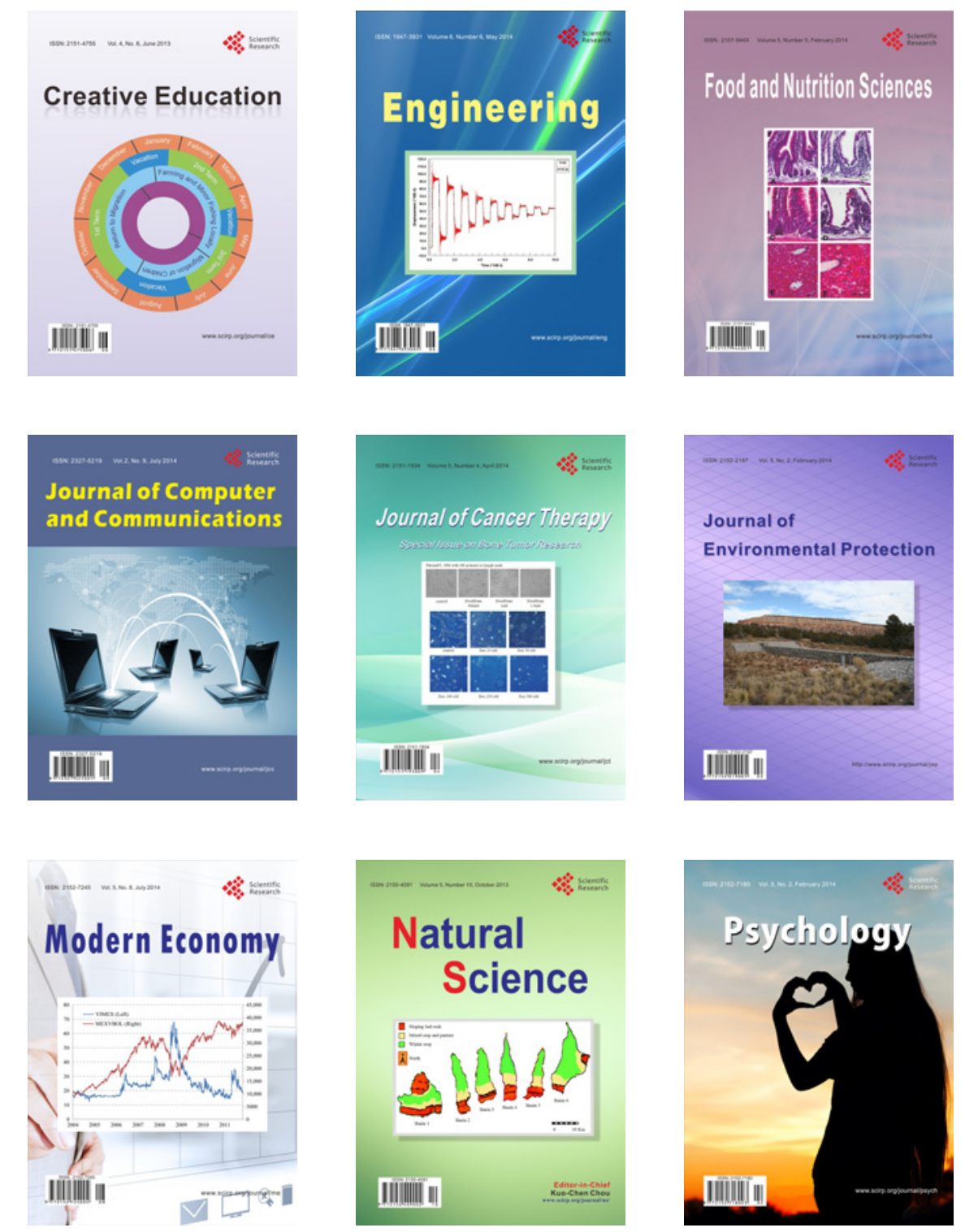